\section{ACTION AGAINST TERRORIST FUNDING}

After the bombing of the World Trade Centre in 1993, one of the bombers reclaimed the deposit on the van, which had been hired and packed with explosives. Following the money trail from there led to the eventual conviction of him and a fellow bomber. One of the payments from the Gulf to an account held in a Florida bank by Mohamed Atta - presumed to be the leader of the hijackers who destroyed the World Trade Centre on 11 September - was reported by the bank as a suspicious transaction to the US authorities. Along with a hundred thousand odd similar reports, no further action was taken with this one (Financial Times, 29 November 2001). Most of the financing for the 11 September attacks, however, were smaller payments or in cash and thus fell under the money laundering reporting net.

That terrorists use the banking system has been recognised by legal developments before 11 September. Most notably the UN International Convention for the Suppression of the Financing of Terrorism was the culmination of several General Assembly Resolutions of the mid-nineties, calling for measures to counteract the movement of funds suspected of terrorist purposes without impeding free capital movements. Not yet in force, the Convention obliges states to create various offences relating to the funding of terrorism and to take measures for the identification, detection, freezing and seizure of such funds and proceeds. In the particular case of the Taliban in Afghanistan, the Security Council imposed a freeze on its funds by Resolutions 1267 of 1999 and 1333 of 2000. This was in recognition of the sanctuary provided by the Taliban to Osama bin Laden, and followed the embassy bombings in Africa in 1998.

The events of 11 September have further galvanised the international community in relation to terrorist funding. Acting under Chapter VII of the UN Charter, the Security Council decided that all states should criminalize the funding or terrorism (the International Convention obligation) and should "freeze without delay funds and other financial assets or economic resources" of terrorists, entities owned by terrorists and those acting for them (Resolution 1373 of 28 September 2001). The UK government was able to take immediate implementing action by order in council under the United Nations Act 1946 in early October (The Terrorism (United Nations Measures) Order 2001, SI 3365/2001). It was not until 27 December that the European Community passed the necessary council regulation (EC) No 2580/2001.

Promoted in part by the events of 11 September, the UK government also enacted the Anti-Terrorism, Crime and Security Act 2001, which amended in important respects the Terrorism Act 2000. As a result there is now an armoury of legal provisions obliging banks to disclose information to the authorities about suspected terrorists, prohibiting banks from making funds available to terrorists and freezing

\section{Articles}

Is Milosevic getting a fair trial at The Hague? 3

The court's role in life and death decisions

University of the Free State honours Director

News

Problems of interpretation by the European Court of Justice of community legislation on equal treatment for men and women

Holding Multinationals to account: Recent Developments in English litigation and the Company Law Review II

terrorist funds held by banks. But how effective are such provisions likely to be? One difference from money laundering is that terrorist funding typically involves much smaller sums, so detection problems are compounded. Another difference is that the sources of terrorist funding are often ostensibly legitimate - the al-Qaeda network ran a range of businesses and financial support also came from a variety of charities. If the legal controls addressing money laundering have not always been a success, will those directed against terrorist funding be any more effective?

The Society of Advanced Legal Studies has established an expert working group to get a handle on these issues and to come up with practical suggestions. The working group comprises five sub-groups, the first to review the legislation itself; the second to examine the impact of initiatives on financial institutions (compliance issues); the third to explore the human rights aspects; the fourth to look at the enforcement issues including international cooperation; and the fifth to gauge the impact on other areas of the law. The different subgroups are hard at work at the time of writing and it is hoped that a report will be completed by late spring. Given the number, experience and commitment of members of the sub-groups, I am confident that the report will have a real impact on the public policy debate.

\section{Ross Cranston QC MP \\ Chairman, SALS Expert Working Group on the Legal Implications of the Interdiction of Terrorist Property}

